\title{
Separative Determination of Ascorbic Acid and Erythorbic Acid in Animal Tissues by High-Performance Liquid Chromatography
}

\author{
Megumi ŌTsuKa, Tadao Kurata, Emiko SuzuKI, \\ Nobuhiko AraKawa, ${ }^{1}$ and Chōten INAGAKI ${ }^{2}$ \\ ${ }^{1}$ Department of Food and Nutrition, Ochanomizu University, \\ Bunkyo-ku, Tokyo 112, Japan \\ ${ }^{2}$ Laboratory of Nutrition, Kyōritsu Women's University, \\ Chiyoda-ku, Tokyo 112, Japan
}

(Received July 17, 1980)

\begin{abstract}
Summary A method for the separation and determination of ascorbic acid (AsA) and erythorbic acid (ErA) in animal tissues is described. It employs high-performance liquid chromatography op a LiChrosorb- $\mathrm{NH}_{2}$ column in conjunction with a mixture of acetonitrile, acetic acid and water as an eluant. Application of the method, which is sensitive, rapid and simple, to the analyses of AsA and ErA in animal tissues such as liver, adrenals, spleen, kidneys and heart gave satisfactory results. DehydroAsA and dehydro-ErA in rat liver could be determined after reduction with $\mathrm{H}_{2} \mathrm{~S}$. The method was shown to be useful for the routine analyses. Key Words separative determination, ascorbic acid, erythorbic acid, animal tissues, high-performance liquid chromatography
\end{abstract}

In the preceding paper (1), we described the method of high-performance liquid chromatography (HPLC) for the separation and determination of ascorbic acid (AsA) and erythorbic acid (ErA). ErA has been widely used as an antioxidant in the food industry. However, the recent report(2) showed that ErA caused a considerable decrease in the availability of AsA when administered together with AsA. Since then, as much attention has been devoted to the antagonist effects of ErA as to its vitamin $\mathrm{C}$ activity. Hence, it is of interest to examine the possible interaction of AsA and ErA in vivo. In studying this interaction, it is inevitably necessary to establish a rapid and specific analysis method for the separation and determination of both isomers.

Several methods for differential determination of AsA and ErA have been reported (3-5). However, these methods have limited application to the analysis of biological samples because the resolution of AsA and ErA and sensitivity of their detection are insufficient to enable the routine use of these methods for the analysis

${ }^{1}$ 大塚 恵, 倉田忠男, 鈴木恵美子, 荒川信彦, ${ }^{2}$ 稲垣長典 
of various biological samples, especially for those of low ErA contents, from experimental animals administered with a small dose of ErA.

The present paper reports the application of the HPLC method to the quantification of AsA in a variety of biological samples, and also, to the separation and estimation of ErA added to them.

\section{EXPERIMENTAL}

Reagents. AsA, ErA and internal standard solution were prepared using the same procedures described in the previous paper(1). A $2 \%$ metaphophoric acid solution was used for extraction of tissues.

Preparation of samples. Wistar strain male rats, 6-7 weeks old, were sacrificed after $24 \mathrm{hr}$ fasting. Their tissues, liver, adrenals, spleen, kidneys and heart, were removed, weighed, kept at $0^{\circ} \mathrm{C}$ until use and homogenized with 5-10 volumes of $2 \%$ metaphosphoric acid to make the AsA concentration about $20 \mu \mathrm{g} \mathrm{AsA} / \mathrm{ml}$. For examples, 5-10 g portions of whole rat liver were homogenized and extracted with $20-40 \mathrm{ml}$ of the extracting solution. The extract was further diluted to yield a $2 \times 10^{-3} \mu \mathrm{g} / \mu \mathrm{l}$ solution of AsA or ErA, and the diluted extract was directly injected into the HPLC apparatus. Concentration of metaphosphoric acid was also adjusted to $0.5 \%$ in order to avoid such undesirable effects on chromatographic performance as observed at its higher concentration in the previous paper $(1)$. The procedure is summarized in Fig. 1.

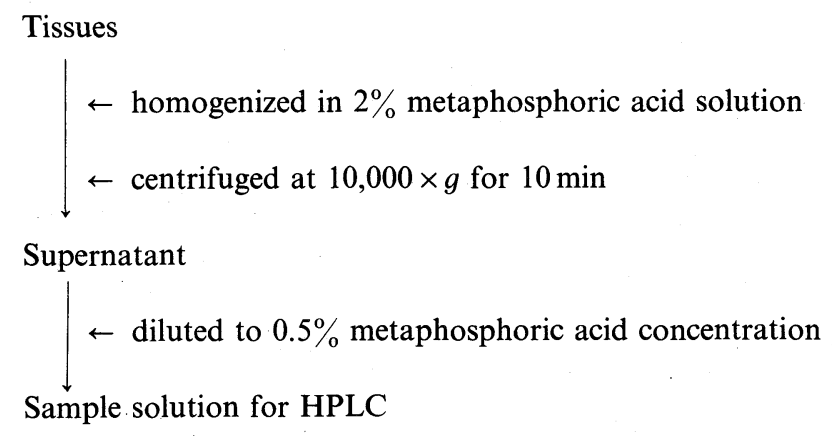

Fig. 1. Preparation of samples for HPLC.

Liquid chromatography. Shimadzu Du Pont LC-2P Liquid Chromatograph was used and the eluate was monitored with a UV detector at $254 \mathrm{~nm}$. A stainless steel column $\left(25 \mathrm{~cm} \times 4 \mathrm{~mm}\right.$ i.d.) was packed with LiChrosorb- $\mathrm{NH}_{2}$. A mixture of acetonitrile, acetic acid and water $(87: 2: 11, \mathrm{v} / \mathrm{v})$ was used as a mobile phase. Before use, the column was pre-conditioned with $30 \mathrm{ml}$ of $0.1 \mathrm{M}$ ammonium monophosphate.

Colorimetric determination. AsA in sample solutions prepared from rat tissues was determined by the 2,4-dinitrophenylhydrazine method (DNP method) (6) as 
described in the previous paper(1).

\section{RESULTS AND DISCUSSIONS}

\section{Determination of AsA in rat tissues}

Table 1 compares the results of the HPLC method and the DNP method employed to determine AsA contents in five different tissues of rat. In the case of the DNP method, which is generally accepted as the most reliable method for AsA determination, the values given represent the contents of the reduced form of AsA which were estimated by subtracting contents of dehydro-AsA and 2,3diketogulonic acid from those of total AsA. The data revealed no significant differences between the two methods of AsA analysis. The AsA contents of these tissues are close to those reported in the literature (7). In the case of the heart extract containing AsA in lower level, the HPLC results appear to be lower than the DNP results. However, the DNP results are of limited accuracy owing to the accompanying high blank values, while the HPLC results were far above the minimum detection level $\left(0.5 \times 10^{-3} \mu \mathrm{g} / \mu \mathrm{l}\right)$ shown in the previous paper $(1)$. It thus appears that the HPLC method is sensitive and practical compared with the DNP method, for determination of AsA in animal tissues.

The reproducibility of the HPLC method was evaluated by making 5 replicate analyses on 4 different liver samples obtained from 4 rats; it was found to be $\pm 5 \%$.

Table 1. Comparison of HPLC method and DNP method for determination of AsA in rat tissues.

\begin{tabular}{lrr}
\hline & \multicolumn{2}{c}{ Concentration of AsA $\left(\mathrm{mg}^{\circ}\right)$} \\
\cline { 2 - 3 } Tissues & HPLC & DNP \\
\hline Liver & 23.0 & 23.1 \\
Adrenal & 274.0 & 289.0 \\
Spleen & 27.1 & 27.6 \\
Kidney & 5.0 & 4.2 \\
Heart & 2.3 & 2.8 \\
\hline
\end{tabular}

Table 2. Consecutive analysis of AsA in rat liver extract.

\begin{tabular}{ccc}
\hline Rat liver & AsA $(\mathrm{mg} \%)$ & S.D./Av. ${ }^{\text {a }}(\%)$ \\
\hline No. 1 & $27.6 \pm 1.2$ & 4.6 \\
No. 2 & $24.3 \pm 0.9$ & 3.7 \\
No. 3 & $21.0 \pm 1.2$ & 5.7 \\
No. 4 & $23.4 \pm 0.9$ & 3.8 \\
\hline
\end{tabular}

a S.D. means standard deviation. Av. means average concentration of AsA. 

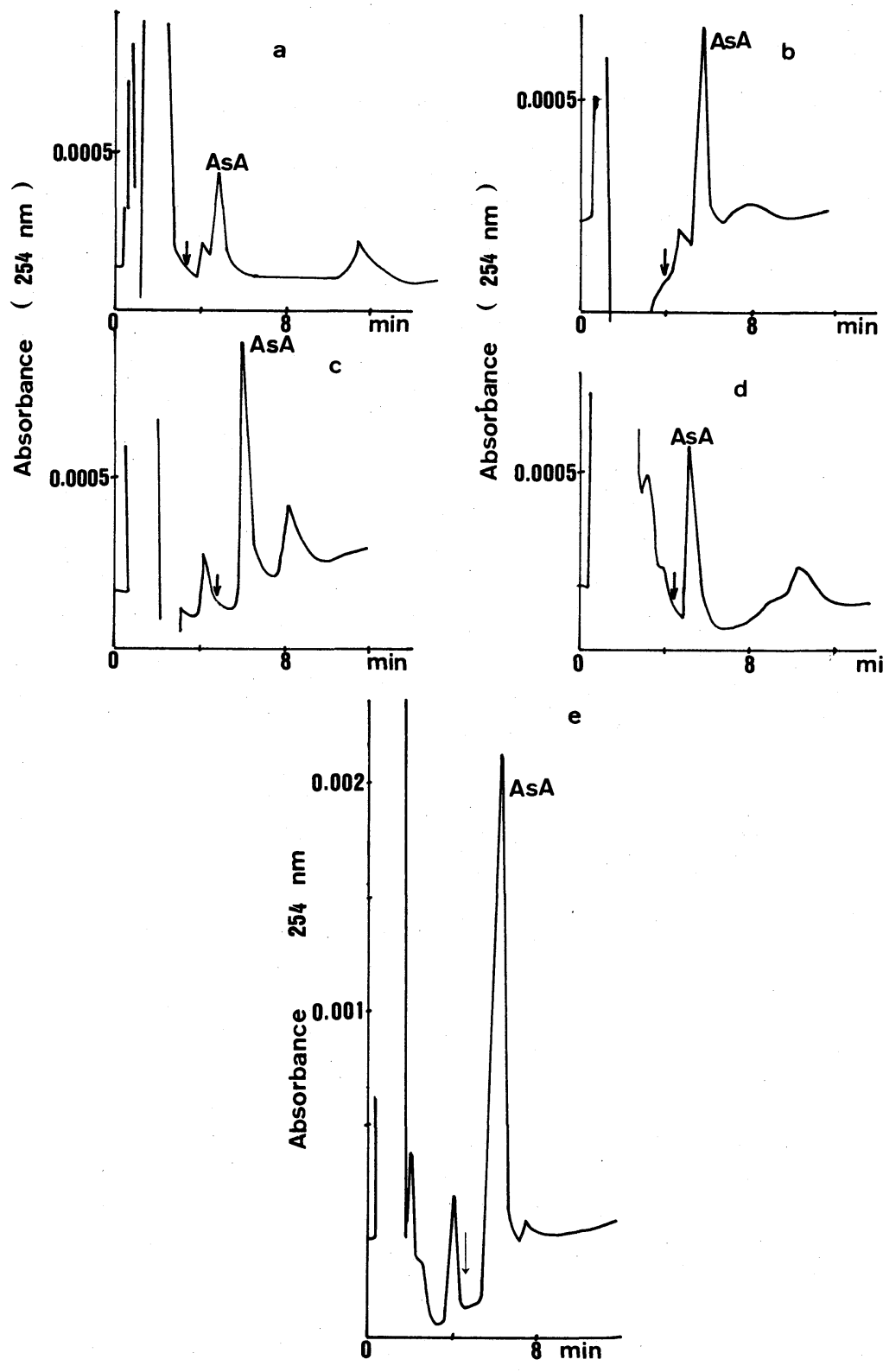

Fig. 2. Chromatograms of the extracts from various tissues of rat. (a) Liver extract diluted to $1: 50$, (b) adrenals extract diluted to $1: 300$, (c) kidneys extract diluted to $1: 5$, (d) heart extract diluted to $1: 5$ in this case, chromatographic condition used is different from those of other extracts, (e) spleen extract diluted to $1: 15$. LiChrosorb$\mathrm{NH}_{2}, 25 \mathrm{~cm} \times 4 \mathrm{~mm}$ i.d. stainless steel column; eluant, acetonitrile : acetic acid : water $(87: 2: 11, \mathrm{v} / \mathrm{v})$. Arrows indicate the position of the ErA peak. 
The experimental data obtained are given in Table 2 .

Figure 2 shows chromatograms of sample solutions obtained from liver, adrenals, spleen, kidneys and heart. There were no other peaks which overlap with the AsA or ErA peak and give rise to significant interference in their determination. In the chromatogram of kidney sample (not shown), an unidentified peak (retention time of about $5.5 \mathrm{~min}$ ) sometimes appeared close to that of AsA and interfered with the precise determination. In this case, AsA content of kidneys was estimated by the extrapolation method, involving the addition $1-5 \times 10^{-2} \mu \mathrm{g}$ AsA to $20 \mu \mathrm{l}$ of the extract solution.

\section{Recovery test for AsA or $\operatorname{ErA}$}

Figure 3 shows chromatograms of ErA added to liver extracts. Figure 3(a) is the chromatogram of the liver extract and Figs. 3(b) and 3(c) are those of the liver extract to which known amounts of ErA were added. These chromatograms show that the peak of ErA added to liver does not overlap with any other inherent peaks.

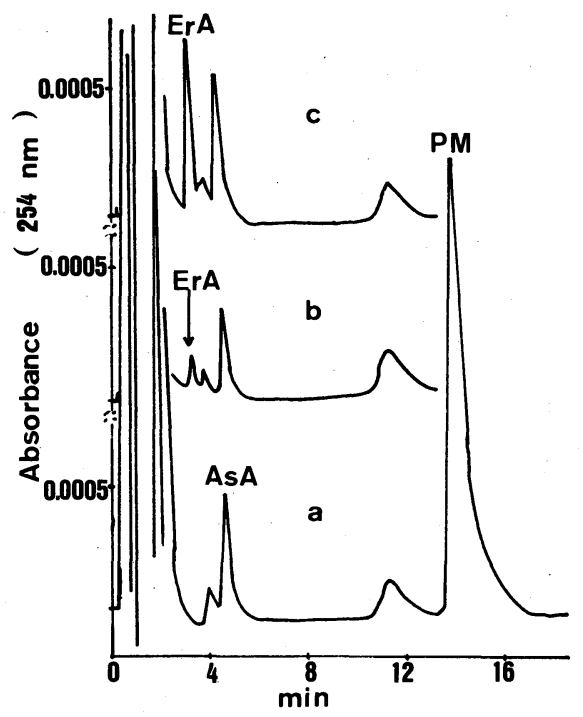

Fig. 3. Chromatogram of AsA present in, and ErA added to, liver extracts. (a) Liver extract containing $8 \times 10^{-2} \mu \mathrm{g}$ of AsA, (b) liver extract fortified with $1.7 \times 10^{-2} \mu \mathrm{g}$ of ErA, (c) liver extract fortified with $4.2 \times 10^{-2} \mu \mathrm{g}$ of ErA. Column, LiChrosorb- $\mathrm{NH}_{2}$; eluant, acetonitrile : acetic acid : water $(87: 2: 11)$; flow rate, $2.8 \mathrm{ml} / \mathrm{min}$.

The results of recovery experiments are given in Table 3. Micro-quantities of AsA or ErA added to liver samples are recovered with no considerable loss.

\section{Recovery from dehydro-AsA or dehydro-ErA added to liver}

The dehydro-form of AsA or ErA added to liver extracts were reduced with $\mathrm{H}_{2} \mathrm{~S}$ and analyzed by HPLC. The results shown in Table 4 suggest that the dehydro- 
Table 3. Recovery of AsA and ErA added to liver extracts.

\begin{tabular}{cccc}
\hline & $\begin{array}{c}\text { AsA or ErA } \\
\text { added } \\
\left(10^{-2} \mu \mathrm{g}\right)\end{array}$ & $\begin{array}{c}\text { AsA or ErA } \\
\text { found } \\
\left(10^{-2} \mu \mathrm{g}\right)\end{array}$ & $\begin{array}{c}\text { Recovery } \\
(\%)\end{array}$ \\
\hline \multirow{3}{*}{ ErA } & 0.00 & 0.00 & - \\
& 0.80 & $0.77 \pm 0.05$ & 110 \\
& 1.70 & $1.67 \pm 0.12$ & 98.2 \\
& 2.50 & $2.47 \pm 0.26$ & 98.8 \\
& 3.30 & $3.60 \pm 0.28$ & 109 \\
AsA & 0.00 & $3.99 \pm 0.20$ & -110 \\
& 0.80 & $4.87 \pm 0.12$ & 94.7 \\
& 1.70 & $5.60 \pm 0.32$ & 117 \\
& 2.50 & $6.93 \pm 0.12$ & 111 \\
\hline
\end{tabular}

Table 4. Recovery of dehydro-AsA and dehydro-ErA added to liver extract after $\mathrm{H}_{2} \mathrm{~S}$ treatment.

\begin{tabular}{cccccccc}
\hline \multicolumn{2}{c}{ Added $(\mu \mathrm{g} / \mathrm{ml})$} & & \multicolumn{2}{c}{ Found $(\mu \mathrm{g} / \mathrm{ml})$} & & \multicolumn{2}{c}{ Recovery $(\%)$} \\
\cline { 1 - 1 } \cline { 7 - 8 } Dehydro-AsA & Dehydro-ErA & \multicolumn{1}{c}{ AsA } & ErA & & AsA & ErA \\
\hline 0 & 0 & $5.0 \pm 0.5$ & 0 & & - & - \\
10.0 & 0 & $15.0 \pm 1.3$ & 0 & & 100 & - \\
0 & 10.0 & & $4.8 \pm 0.2$ & $10.5 \pm 0.2$ & & - & 105 \\
\hline
\end{tabular}

form of AsA or ErA in liver extract can be determined by this method with satisfactory accuracy.

\section{Improvement on resolution of the column used for a long period}

The column packed with LiChrosorb- $\mathrm{NH}_{2}$ could be used for the analyses of AsA or ErA in the animal tissues for over 200 consecutive hours with no apparent loss in column efficiency. Throughout this investigation, retention times of ErA and AsA were about 3-4 and 4-6 min, respectively, and their resolution was retained as adequate. When their resolution had to be improved, the composition of the mobile phase was modified as described in the previous paper (1).

Analysis of AsA in other biological samples, urine and blood for exmaple, might present some difficulties because of a possible occurrence of interfering substances in the samples. Undesirable effects of these interfering substances may presumably be removed by introducing a pre-column or by including other fractionation procedures prior to the HPLC analysis. 
The HPLC method employed in this study is effective for determination of AsA and $\mathrm{ErA}$ in the samples from animal tissues such as liver, adrenals, spleen, kidneys and heart. Dehydro-forms of AsA and ErA in these animal tissues can be also determined after reduction with $\mathrm{H}_{2} \mathrm{~S}$. Thus, the method has potential application in the routine, consecutive analyses of certain biological samples because it permits rapid and accurate determination of very small quantities of AsA and ErA.

\section{REFERENCES}

1) Arakawa, N., Ōtsuka, M., Kurata, T., and Inagaki, C. (1981): Separative determination of ascorbic acid and erythorbic acid by high performance liquid chromatography. $J$. Nutr. Sci. Vitaminol., 27, 1-7.

2) Hornig, D. (1977): Interaction of erythorbic acid with ascorbic acid catabolism. Acta Vitaminol. Enzymol. (Milano), 31, 9-14.

3) Brenner, G. S. (1964): Isomerization of the ascorbic acids. J. Org. Chem., 29, 2389.

4) Miki, T., and Sahashi, Y. (1962): Paper chromatographic separation of L-ascorbic acid and D-araboascorbic acid. Vitamins (in Japanese), 25, 171-177.

5) Miki, T., and Sahashi, Y. (1962): Paper chromatographic separation and estimation of L-ascorbic acid and D-araboascorbic acid. Vitamins (in Japanese), 25, 178-182.

6) Mayer Freed, Chairman (1966): Methods of Vitamin Assay, Association of Official Vitamin Chemists, 3rd ed., Interscience Publ., New York, pp. 317-332.

7) Tsujimura, M., Uchiyama, Y., and Fujita, A. (1971): On the fractional determination of ascorbic, dehydro ascorbic, and diketogulonic acids. Vitamins (in Japanese), 43, 210-220. 